\title{
Synthesis and Adhesion Study of Eco-Economical Green Adhesive for Wood Made from Soy Protein Isolates Cross-Linked with Cinnamaldehyde
}

\author{
POORVESH D. RATHOD ${ }^{1}$, KALPESH PATEL $^{2}$ and JIGAR V. PATEL ${ }^{1 *}$ \\ ${ }^{1}$ Department of Industrial Chemistry, Institute of Science and Technology for Advanced \\ Studies and Research (ISTAR), Vallabh Vidyanagar, Anand, Gujarat, 388120, India \\ ${ }^{2}$ Surface Coating and Technology Department, Institute of Science and Technology for \\ Advanced Studies and Research (ISTAR), Vallabh Vidyanagar, Anand, Gujarat, 388120, \\ India \\ pramukhprit@yahoo.co.in
}

Received 14 November 2017 / Accepted 30 November 2017

\begin{abstract}
Green adhesives that can be used for wood were synthesized using soy protein isolates. The denaturation of soy protein isolates was done by the alkali and cross-linked with naturally occurring cross-linker to produce cross linked network. The cross-linking reaction was confirmed by the sodium dodecyl sulfate-polyacrylamide gel electrophoresis (SDS-PAGE) analysis. Differential scanning calorimetry (DSC) was used to study the thermal properties of prepared adhesives. The evaluation of bonding strength of the prepared adhesives was done on Plywood substrate. Curing time was determined by bonding the plywood pieces for 12 hours and subjected to lap shear test. The study of bond strength after treatment with cold water, hot water, acid and alkali was done. The pot life of prepared adhesives were studied and found to be superior to the other available green adhesives.
\end{abstract}

Keywords: Soy protein isolates, Denaturation, Cross-linked network, Green Adhesives, Wood

\section{Introduction}

Chemistry play important role in our life from last few decades and made the life comfortable through thousands of value added products. The petroleum is used as primary building block to developing these products. But the use of non-renewable petroleum is very energy sensitive, inefficient and toxic, resulting in significant energy use and generation of hazardous waste.

Adhesives are also one class of end use products which are derived from non-renewable petroleum sources. About 20 billion pounds of adhesives are used annually in the United States. Among these adhesives, about 8 billion pounds are formaldehyde based adhesive, 3.5 billion pounds are thermoset and thermoplastic based adhesive, 7.5 billion pounds are latex 
based adhesive, 0.5 billion pounds are isocyanate based and rest are various adhesive with unique application ${ }^{1}$. The formaldehyde based adhesive primarily include urea formaldehyde and phenol formaldehyde adhesive which are mainly used for plywood, particle board, medium density fibre board and oriented standard board for construction. But these formaldehyde based adhesive has health related and pollution related concerns. The formaldehyde emission during the application of wood adhesive found to be carcinogenic according to world health organization $(\mathrm{WHO})^{2-4}$. Also the prize fluctuations of petroleum sources are high due to limited reserve oil. So the immense pressure on researcher to develop techniques which would greatly reduce risk to fenceline communities and safer products for manufacturers and consumers. This would consume less raw material and energy as well as save money on waste disposal.

The conversion of bio mass to useful material such as polymers and composites has considerable economic and environmental value, particularly in the times of global warming and diminishing petroleum oil reserves. This development offers significant opportunities for new, improved green material from renewable resources that are optionally recyclable, bio-compatible and bio-degradable. The bio based material is consistent with the design, commercialization and the use of processes and products that are technically and economically feasible wise minimizing the generation of pollution at the source and risk to human health and environment.

Researchers are trying to develop adhesive from renewable resources. Sun and Bian in 1999 , found that urea modified soy protein adhesive were more water resistant than those modified by alkali ${ }^{5}$. Zhong and sun in 2002, investigated adhesive properties of soy protein modified with different concentrations of urea and guanidine hydrochloride ${ }^{6}$. Chengsheng and his team found that polyamido amine epichlorohydrin resin has been found to be excellent curing agent for soybean protein in $2013^{7}$. Yuan Liu produced novel adhesive based on soy flour, maleic anhydride and polyethylene imine in $2007^{8}$. Soy protein also modified with enzymes including trypsin ${ }^{9}$, papain and urease ${ }^{10}$.

The adhesive prepared from renewable resources are facing the problem of lacking in water resistance property. To improve water resistance of soy protein adhesives, several class of cross-linking agents have been used are non-renewable. Also the enzymes used to improve water resistance but they are quite costly, so that the resultant adhesive products are not economical. The present work comprises of development of adhesive from renewable resources i.e. soy protein isolates, sodium hydroxide and cinnamaldehyde cross-linker.

Soybean de oiled cake is free flowing coarse granular material, produced from cleaned soybean seeds after series of preparatory physical processes followed by multistage extraction. Globally, about $98 \%$ of soybean meal is used as animal feed. Soybean de oiled cake contains $45-50 \%$ protein, which can be extracted by different methods. Acid-alkali method was used for the extraction of protein from soybean de oiled cake in the present work. Sodium hydroxide is strong alkali agent which can denature the protein structure ${ }^{10}$. Cinnamaldehyde is an organic compound with the chemical formula $\mathrm{C}_{6} \mathrm{H}_{5}-\mathrm{CH}=\mathrm{CH}-\mathrm{CHO}$. Cinnamaldehyde is naturally occurring as pale yellow, viscous liquid in the bark of cinnamon trees and other species of genus cinnamomum which grows in south India. cinnamaldehyde is non-toxic, but it can irritate skin if in contact for too long. No agencies suspect the compound is a carcinogenic or poses a long term health hazards.

The objective of this work is to find out the optimal conditions to synthesizing wood adhesive with good performance. To achieve this, for each fix quantity of sodium hydroxide, different quantity of cinnamaldehyde was added at different temperature to develop strong 
cross-linked network. The chemistry behind this practice is that the protein can be denatured by strong alkali agents. So sodium hydroxide was added in the fixed amount for protein denaturation. Denaturation technique in which, protein undergoes structural changes from quaternary to primary without affecting the peptide linkage of protein. The unfolding of protein structure contains large numbers of free amino group that can be reacting with aldehyde group of cinnamaldehyde to develop cross-linked network. The resulted bioadhesive used to prepare wood panels.

\section{Experimental}

Soybean de oiled cake was obtained from Charotar animal feed Pvt. Ltd., Vitthal Udyognagar, Anand, Gujarat, India. The chemicals used for the experiments were purchased from Chiti-Chem Corporation, Vadodara, Gujarat, India. Demineralized water was used for the preparation of all adhesive mixture.

\section{Preparation of soy protein isolates}

Soybean de oiled cake was dissolved in freshly prepared $0.25 \mathrm{~N}$ standard solution of sodium hydroxide. Soybean to standard sodium hydroxide solution ratio was 1:20. The mixture was stirred for two hours at temperature $40-50{ }^{\circ} \mathrm{C}$. Then cooled at room temperature and filtered in a centrifuge. The filtrate was taken and acidified it with standard solution of $0.50 \mathrm{~N}$ hydrochloric acid. After acidification, precipitates occurred which were collected and dried at a room temperature. After completion of drying, protein isolates were crushed into grinder to obtain the fine powder. This Fine powder was used for the preparation of bio-adhesive.

\section{Adhesive preparation}

The production of wood adhesive was involving the reaction of protein with cinnamaldehyde in alkali condition. Sodium hydroxide was used to provide an alkaline condition. Demineralized water and soy protein isolates at ratio of 4:1 were first mixed together in a three neck round bottom flask by mechanical motor stirrer for 5 minutes. Subsequently, sodium hydroxide was added drop by drop to the mixture over a period of 8-10 minutes. The reaction mixture was left for two hours. Then cinnamaldehyde crosslinker was added and mixture was stirred for another two hours to develop cross- linked network structure.

\section{Wood preparation}

The plywood was cut into strips as per ASTM D 1002. They were polished with sandpaper of grit no.60 $(250 \mu \mathrm{m})$.

\section{Wood bonding and testing}

The resultant adhesive was applied on both pieces of wood strip as per ASTM D 1002 by using the brush. The applied adhesive had a thickness of $0.1 \mathrm{~mm}$. Applied adhesive was then allowed to penetrate into wood layers in open air for few second. After that both pieces was overlapped on each other and fixed with clamps. These wood joints were subjected to lap shear test by using Shimadzu AG-100kN universal testing machine with the use of Win-soft tensile and compression testing software.

\section{Sodium dodecyl sulfate-polyacrylamide gel electrophoresis (SDS-PAGE)}

SDS-PAGE analysis was done for the conformation of cross linking reaction. Cross linking of protein with cross linker will leads to formation of complex network. SDS-PAGE in a single electrophoresis run can be divided into stacking gel and separating gel. Stacking gel 
with 5\% acryl amine was poured on top of separating gel after solidification and the gel comb was inserted into stacking gel. For making separating gel two glass plates clamped in the casting frames on the casting stands. The gel solution as described above in separate small beaker and stirred gently but thoroughly. Appropriate amount of separating gel was pipette out into the gap between glass plates to make the top of the separating gel be horizontal. Water was filled in the gap until overflow and then waited for 20-30 minutes to let in gelate. For making stacking gel water was discarded and water was left. After that, pipette out in stacking gel until overflow. The well forming comb without trapping was inserted under the teeth and waited for 20-30 minutes to let it gelate. After gelation, the comb was taken out and the glass plates were also taken out of casting frame and allowed to set them in the cell buffer dam. The running buffer was poured into the inner chamber until the buffer surface reaches the required level in the outer chamber. Then samples were prepared by mixing with sample buffer and heated in boiling water for 5-10 minutes. The prepared sample was loaded into wells. The control protein was loaded into the first lane, after which top was covered and connected to anodes. The electrophoresis was run for 1 hour at $120 \mathrm{~V}$ voltage and $12 \%$ separating gel.

\section{Differential scanning calorimetry (DSC)}

The conformation of denaturation of protein was accomplished by DSC method. The rupture of intra and intermolecular bonds leads transition of protein from native to denature state. The energy involved in rupture of intra and intermolecular bonds can be detected by differential scanning calorimetry. The energy was calculated as the area of denaturation of peaks. To obtain denaturation peak, DSC was performed which was calibrated with indium and zinc in the nitrogen atmosphere. DSC pan was used to hold about $50 \mathrm{mg}$ of sample. All the samples were held at $25^{\circ} \mathrm{C}$ for 1 minute and then scanned from $25^{\circ} \mathrm{C}$ to $180{ }^{\circ} \mathrm{C}$ at a heating rate of $10^{\circ} \mathrm{C} /$ minute.

\section{Effect of quantity of sodium hydroxide on lap shear strength}

To determine the effect of sodium hydroxide on lap shear strength, two different quantity of sodium hydroxide was added while formulation.

\section{Effect of reaction temperature}

To study the effect of temperature of reaction on the development of cross-linked network structure, the adhesive preparation was done at room temperature and $45^{\circ} \mathrm{C}$.

\section{Determination of curing time}

Curing time is a time required by the resin to get harder. For determination of curing time, the wood joints were clamped for 12 hours and then conditioned at room temperature for five days and were subjected to lap shear test.

\section{Performance under different environmental condition}

To study the effect of different environmental condition, wood joints were treated under cold water, hot water, acidic water $(\mathrm{pH} 2)$ and alkali water $(\mathrm{pH} \mathrm{10)}$ by using different methods. The cold water treatment was done by immersing wood joints in cold water at room temperature for 24 hours and dried at room temperature for five days and subjected to lap shear test. The hot water treatment was performed by immersing separate group of wood joints in hot water at $80{ }^{\circ} \mathrm{C}$ for 1 hour and dried at room temperature for five days and subjected to lap shear test as described earlier. Another group was immersed into acidic water of $\mathrm{pH} 2$ for $1 \mathrm{~h}$ and another group was immersed into alkali water of $\mathrm{pH} 10$ for $1 \mathrm{~h}$. Both groups were dried for five days and subjected to lap shear test. 


\section{Comparison with other renewable adhesives}

To determine the effectiveness of resultant bio-adhesive produced from earlier method, comparison was done with different bio-adhesive prepared by different research groups. The comparison was done by collecting the data of lap shear test from literature survey ${ }^{11,12}$.

\section{Comparison with commercial wood adhesive}

Fevicol $^{\circledR}$ is the most commonly used adhesive brand for wood to wood joint in India was selected for the comparison. The best performing resin 4.3 was compared with Fevicol ${ }^{\circledR}$.

\section{Pot life}

Pot life is an important characteristic of adhesive. The adhesive system must be in fluid condition so that it can penetrate easily into the pores of wood substrate. Good penetration can lead to increase adhesion strength. The pot life of resultant adhesive was studied by keeping adhesive mixture into an air tight close container for certain days to see the solidification was occurred or not.

\section{Results and Discussion}

\section{SDS- PAGE}

SDS-PAGE pattern obtained from SDS-PAGE analysis for soy protein isolates which was treated with Sodium hydroxide and cinnamaldehyde was different as compared to soy protein isolates treated only with sodium hydroxide (Figure 1). Compare to soy protein isolates treated only with sodium hydroxide, cross-linked protein show single band which suggest that polymerization has been occurred. Three samples was loaded in the cell, first sample was of soy protein isolates treated only with sodium hydroxide. The protein treated with sodium hydroxide and cross-linked with $5 \mathrm{~g}$ cinnamaldehyde and $7 \mathrm{~g}$ cinnamaldehyde was loaded in the second and third cell respectively. No single band was observed in the first cell. The SDS-PAGE gave sharper band in the third cell than second cell indicates that more cross-linking was occurred.

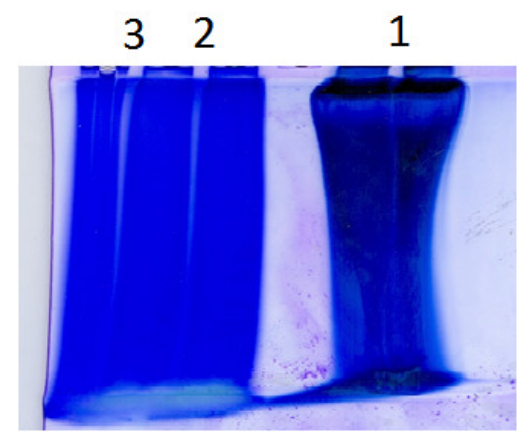

Figure 1. SDS PAGE (1. Control sample, 2. Soy protein isolates cross-linked with $5 g$ Cinnamaldehyde, 3. Soy protein isolates cross-linked with $7 g$ cinnamaldehyde)

\section{Differential scanning calorimetry}

Differential scanning calorimetry is a thermal analysis technique that looks at how a material's heat capacity is changed by temperature. A sample of known mass is heated or cooled and changes in its heat capacity are tracked as changes in the heat flow. Figure 2(a) dedicated to thermogram of control sample which was soy protein isolates treated only with sodium hydroxide. The $\mathrm{T}_{\mathrm{d}}$ for control sample was $52.28{ }^{\circ} \mathrm{C}-113.23{ }^{\circ} \mathrm{C}$ and $\Delta \mathrm{H}_{\mathrm{d}}$ of $85.95 \mathrm{~J} / \mathrm{g}$. 
Figure 2(b) dedicated to thermogram of resin sample which was soy protein isolates treated with sodium hydroxide and cross-linked with $7 \mathrm{~g}$ of cinnamaldehyde in our laboratory. The $\mathrm{T}_{\mathrm{d}}$ value for resin sample was $138.54{ }^{\circ} \mathrm{C}-142.72{ }^{\circ} \mathrm{C}$ and $\Delta \mathrm{H}_{\mathrm{d}}$ of $969.07 \mathrm{~J} / \mathrm{g}$. The results indicate that the enthalpy required for the rupture of bond was higher for cross-linked resin sample than the control sample. From the results, we assumed that higher molecular weight polymer was formed due to cross-linking between soy protein isolate and cinnamaldehyde. The results obtained from experiments shows that when only sodium hydroxide was added in the reaction mixture then resultant product had no adhesive properties. The same result was observed when only cinnamaldehyde was added into the reaction mixture.

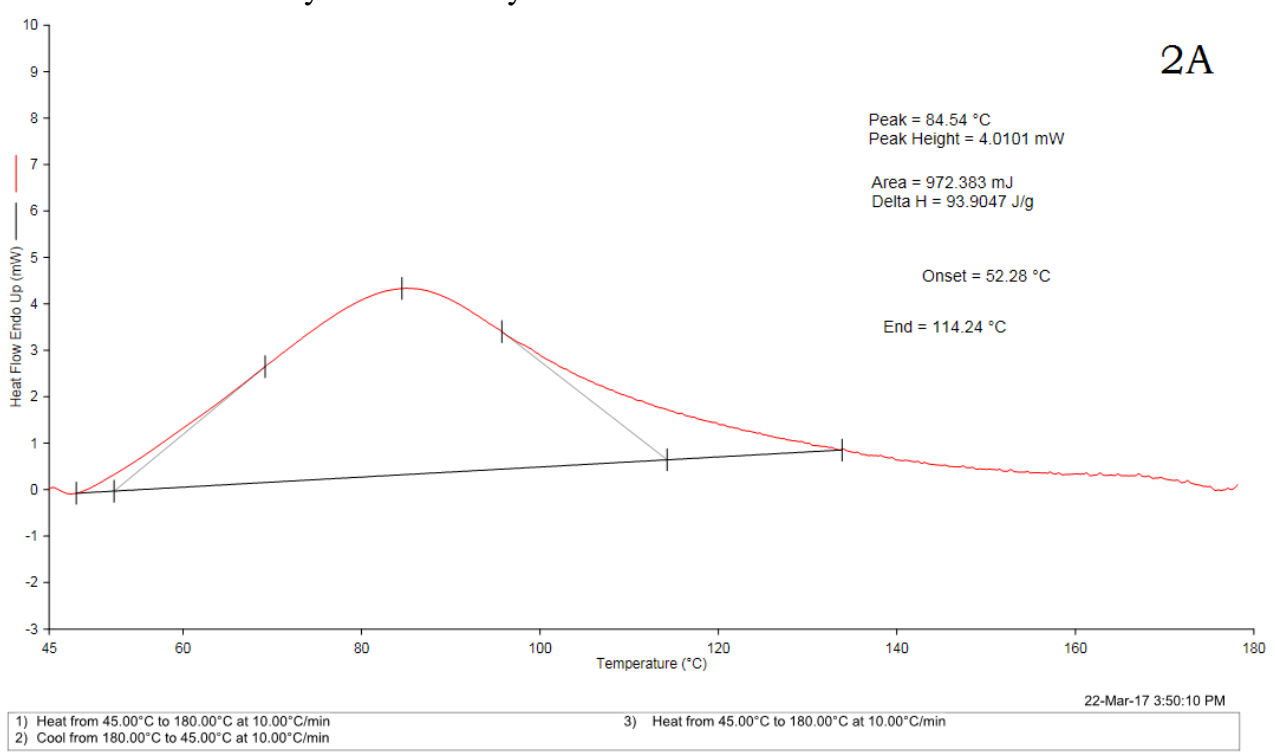

Figure 2a. Thermogram of control sample

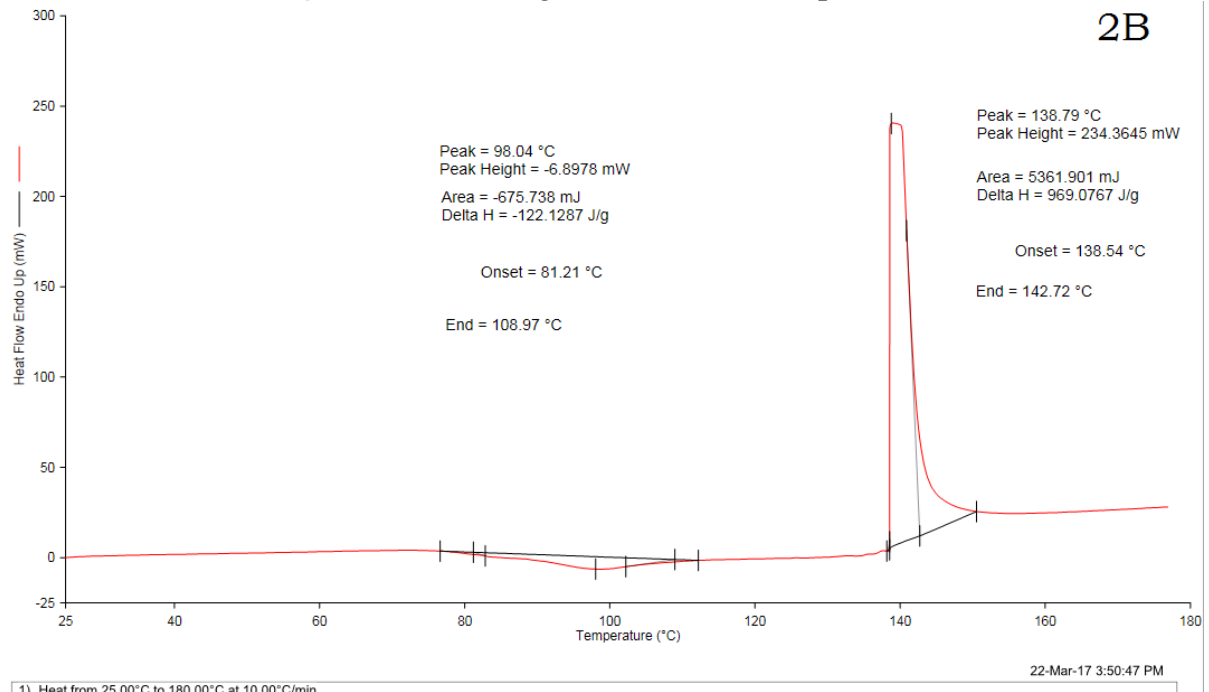

Figure 2b. Thermogram of resin sample 
The data from Table 1 shows that increase in adhesion strength of wood joints because of increase in cinnamaldehyde quantity for fixed quantity of sodium hydroxide added. This may be because of addition of fixed quantity of sodium hydroxide brings hydrolysis of soy protein isolates. Hydrolysis breaks the peptide bonds of the peptide backbone, causing cleavage of both primary and secondary structure. Hydrolysis of protein leads to increase the number of free amine and carboxylic acid functional groups. Protein hydrolysis decreases peptide chain length and reduces both viscosity and molecular size. Short peptide chains have more functional groups exposed, which was believed to enhance the reaction of soy protein with cinnamaldehyde in adhesive formulation. We assumed that if hydrolysis products are too small than the functional properties can be lost. The other possible reason for increase in adhesion strength of wood joints was that the Sodium hydroxide also brings denaturation of soy protein isolates. The phenomenon of disorganization of native protein structure is known as denaturation. Denaturation results in the loss of secondary, tertiary and quaternary structure of proteins. We believed that this involves a change in physical, chemical and biological properties of protein molecules. This unfolding of protein structure increased amine functional groups. These amine functional groups required cinnamaldehyde for polymerization reaction. This polymerization leads to development of complex network structure and thus increases in molecular weight. We assumed that this complex network exhibits the adhesive properties. The results of Table 1 indicate that resin 1.1 contains certain free amine functional groups but cinnamaldehyde was not present in sufficient amount to react with all free amine groups in the formulation. Because of this reason weak cross-linked network was established which gave poor lap shear strength. At the same time, resin 1.2 gave good lap shear strength because of sufficient amount of cinnamaldehyde present in the formulation. The results also shows that excess quantity of cinnamaldehyde may cause over cross-linking and this may increase molecular weight so high that resultant adhesive product may get solidified and thus not used for performance testing.

Table 1. Lap shear strength of different adhesives

\begin{tabular}{|c|c|c|c|c|c|c|c|}
\hline 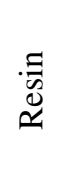 & 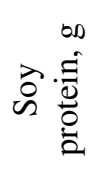 & 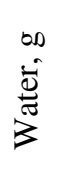 & $\begin{array}{l}\mathrm{NaOH}, \\
\mathrm{g}\end{array}$ & $\begin{array}{c}\text { Cinnamaldehyde, } \\
\mathrm{g}\end{array}$ & 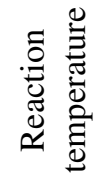 & 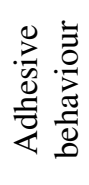 & $\begin{array}{l}\text { Lap shear strength of } \\
\text { plywood specimens after } \\
\text { curing time of } \\
12 \mathrm{~h}\end{array}$ \\
\hline 1.1 & 10 & 40 & 1 & 1 & $\begin{array}{l}\text { Room } \\
\text { temp. }\end{array}$ & Fluid & $0.209 \mathrm{MPa}$ \\
\hline 1.2 & 10 & 40 & 1 & 2 & $\begin{array}{l}\text { Room } \\
\text { temp. }\end{array}$ & Fluid & $0.840 \mathrm{Mpa}$ \\
\hline
\end{tabular}

The results from Table 2 indicate that increase in added quantity of sodium hydroxide may increase the hydrolysis reaction and result of that more amine functional groups released that required more cinnamaldehyde to react to form complex network. Increased number of amine functional group will react with more cinnamaldehyde and will make powerful cross-linked network structure. Less quantity of cinnamaldehyde may not able to produce good cross-linked network leads to decrease in adhesive performance. Optimum quantity of cinnamaldehyde gave good adhesive performance. Higher level of cinnamaldehyde may cause over cross-linking reaction resultant into decrease in adhesive performance. We also believed that at optimum sodium hydroxide quantity, more hydrogen bonds are formed between substrate and adhesive resulting into good adhesive performance. 
Table 2. Lap shear strength of different adhesives

\begin{tabular}{|c|c|c|c|c|c|c|c|}
\hline 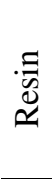 & 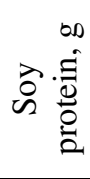 & 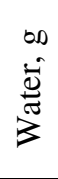 & 克 & $\begin{array}{c}\text { Cinnamaldehyde, } \\
\mathrm{g}\end{array}$ & 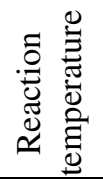 & 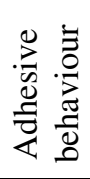 & $\begin{array}{l}\text { Lap shear strength of } \\
\text { plywood specimens after } \\
\text { curing time of } \\
12 \mathrm{~h}\end{array}$ \\
\hline 2.1 & 10 & 40 & 2 & 5 & $\begin{array}{l}\text { Room } \\
\text { temp. }\end{array}$ & Fluid & $0.331 \mathrm{MPa}$ \\
\hline 2.2 & 10 & 40 & 2 & 6 & $\begin{array}{l}\text { Room } \\
\text { temp. }\end{array}$ & Fluid & $0.414 \mathrm{MPa}$ \\
\hline 2.3 & 10 & 40 & 2 & 7 & $\begin{array}{l}\text { Room } \\
\text { temp. }\end{array}$ & Fluid & $0.495 \mathrm{MPa}$ \\
\hline
\end{tabular}

The data from Table 3 and 4 shows that increase in temperature may increase the adhesive performance. The resultant cross-linked structure found more powerful than the structured formed at room temperature. But when the cinnamaldehyde quantity increased, due to high temperature over cross-linking would be occurred and because of this reason adhesive performance of the resultant product was quite low.

Table 3. Lap shear strength of different adhesives

\begin{tabular}{|c|c|c|c|c|c|c|c|}
\hline 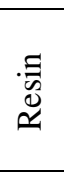 & 官 $\frac{0}{0}$ & 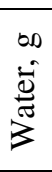 & 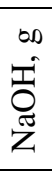 & $\begin{array}{c}\text { Cinnamaldehyde } \\
\mathrm{g}\end{array}$ & $\begin{array}{l}\text { Reaction } \\
\text { temperature }\end{array}$ & $\begin{array}{l}\text { Adhesive } \\
\text { behaviour }\end{array}$ & $\begin{array}{c}\text { Lap shear strength of } \\
\text { plywood specimens } \\
\text { after curing time of } \\
12 \mathrm{~h}\end{array}$ \\
\hline 3.1 & 10 & 40 & 1 & 1 & $45^{\circ} \mathrm{C}$ & Fluid & $0.552 \mathrm{MPa}$ \\
\hline 3.2 & 10 & 40 & 1 & 2 & $45^{\circ} \mathrm{C}$ & Fluid & $0.567 \mathrm{MPa}$ \\
\hline
\end{tabular}

Table 4. Lap shear strength of different adhesives

\begin{tabular}{|c|c|c|c|c|c|c|c|}
\hline$\stackrel{\Xi}{\Xi}$ & 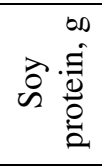 & $\begin{array}{l}\infty 00 \\
\dot{0} \\
\dot{\tilde{\omega}} \\
3\end{array}$ & 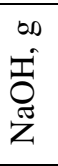 & $\begin{array}{c}\text { Cinnamaldehyde } \\
\mathrm{g}\end{array}$ & $\begin{array}{l}\text { Reaction } \\
\text { temperature }\end{array}$ & $\begin{array}{l}\text { Adhesive } \\
\text { behaviour }\end{array}$ & $\begin{array}{c}\text { Lap shear strength of } \\
\text { plywood specimens } \\
\text { after curing time of } \\
12 \text { hour }\end{array}$ \\
\hline 4.1 & 10 & 40 & 2 & 5 & $45^{\circ} \mathrm{C}$ & Fluid & $0.370 \mathrm{MPa}$ \\
\hline 4.2 & 10 & 40 & 2 & 6 & $45^{\circ} \mathrm{C}$ & Fluid & $0.387 \mathrm{MPa}$ \\
\hline 4.3 & 10 & 40 & 2 & 7 & $45^{\circ} \mathrm{C}$ & Fluid & $0.410 \mathrm{MPa}$ \\
\hline
\end{tabular}

The data shown in Table 5 indicate that resin developed at higher temperature had better cold water, acid and alkali resistance respectively. This may be because of more stable cross-linked network produced at high temperature. But at the same time resultant adhesive had poor hot water resistance. We assumed that this may be because of immersing time of wood joint in hot water was quite more. So as the time passes, stability of cross linked network may get decreased. Also the cross-linked structure may not withstand the higher temperature and also the interlocking bonds between substrate and adhesive at higher temperature may breaks. The other possible reason was that in presence of hot water, the wood will expand beyond the saturation point of its fibers and shrink back when it dries causing dimensional changes and this accelerates the degradation in mechanical interlocking and thus, lower the wood strength.

The comparison of lap shear strength of adhesives produced in our laboratory with other renewable adhesives is shown in Table 6 . We took our best performing resin 4.3 for 
comparison with other renewable adhesives. It was found that bond strength was quite less but at the same time, pot life of adhesive prepared in our laboratory was quite higher. The data of pot life (in days) are shown in Table 8.

Table 5. Environmental resistance of different adhesives

\begin{tabular}{ccccc}
\hline Resin & $\begin{array}{c}\text { Original } \\
\text { strength }\end{array}$ & $\begin{array}{c}\text { After water } \\
\text { treatment }\end{array}$ & $\begin{array}{c}\text { After acid } \\
\text { treatment }\end{array}$ & $\begin{array}{c}\text { After alkali } \\
\text { treatment }\end{array}$ \\
\hline 4.1 & $0.370 \mathrm{MPa}$ & $0.022 \mathrm{MPa}$ & $0.014 \mathrm{MPa}$ & $0.009 \mathrm{MPa}$ \\
4.2 & $0.387 \mathrm{MPa}$ & $0.010 \mathrm{MPa}$ & $0.008 \mathrm{MPa}$ & $0.006 \mathrm{MPa}$ \\
4.3 & $0.410 \mathrm{MPa}$ & $0.006 \mathrm{MPa}$ & $0.004 \mathrm{MPa}$ & $0.003 \mathrm{MPa}$
\end{tabular}

Table 6. Comparison with other renewable adhesives

Table 7. Pot life

\begin{tabular}{cc}
\hline Resin & $\begin{array}{c}\text { Lap shear } \\
\text { strength }\end{array}$ \\
\hline Soy protein-Glutaraldehyde resin & $3.00 \mathrm{MPa}$ \\
Soy flour-furfural resin & $3.68 \mathrm{MPa}$ \\
Soy protein-Cinnamaldehyde resin & $0.41 \mathrm{MPa}$ \\
\hline
\end{tabular}

\begin{tabular}{cc}
\hline Resin & Pot life (Days) \\
\hline 4.1 & 186 \\
4.2 & 205 \\
4.3 & 268 \\
\hline
\end{tabular}

The data shown in Table 8 compares the bond strength of wood joint prepared by adhesive prepared in our laboratory with commercially available adhesive. Fevicol ${ }^{\circledR}$ is used most widely in India. So Fevicol ${ }^{\circledR}$ was used for comparison. It was found that bond strength of adhesive prepared in our laboratory had half of strength than the commercially available Fevicol ${ }^{\circledR}$.

Table 8. Comparison with other commercial adhesive

\begin{tabular}{cc}
\hline Product & Lap shear strength \\
\hline Fevicol $^{\circledR}$ & $1.825 \mathrm{MPa}$ \\
\hline Soy protein-Cinnamaldehyde resin & $0.410 \mathrm{MPa}$ \\
\hline
\end{tabular}

\section{Conclusion}

1. Resin 4.3 was found to give superior bonding properties.

2. As the amount of sodium hydroxide increased, denaturation of protein structure also increased.

3. Increase in reaction temperature leads to better cross-linking reaction and resultant products have good performance.

4. As the quantity of Cinnamaldehyde increases or decreases beyond optimum limit than the adhesive performance decreases.

5. Adhesive developed in our laboratory has good resistance to cold water, acid and alkali but poor resistance to hot water.

6. Highly cross-linked network had shorter pot life.

\section{References}

1. Edward M Petrie, Handbook of Adhesives and Sealants, Mc Graw-Hill Publication, New York.

2. White J T, Adhes Age, 1981, 7-19.

3. Myres G E, Adhes Age, 1988, 10-31.

4. Ebewela R O, River B H and Myres G E, Adhes Age, 1993, 12-23.

5. Sun X S and Bian K, J Am Oil Chem Soc., 1999, 76(8), 977-980; DOI:10.1007/s11746-999-0115-2

6. Zhong Z K, Sun X S, Fang X H and Ratto J A, Int J Adhesion Adhesives, 2002, 22, 267-272; DOI:10.1016/S0143-7496(02)00003-9 
7. Chengsheng Gui, Guyue Wang, Di Wu, Jin Zhu and Xiaoqing Liu, Int J Adhesion Adhesives, 2013, 44, 237-242; DOI:10.1016/j.ijadhadh.2013.03.011

8. Yuan Lui and Kaichang Li, Int $J$ Adhesion Adhesives, 2007, 27(1), 59-67; DOI:10.1016/j.ijadhadh.2005.12.004

9. Hettiarachchy N S, Kalapathy U and Myers D J, J Am Oil Chem Soc., 1995, 72, 14611464; DOI:10.1007/BF02577838

10. Kumar R Choudhary, Mishra V and Varma S, J Adhesion Sci Technol., 2004, 18, 261-273; DOI:10.1163/156856104772759458

11. Emmanuel Lepine, Bernard Riedl, Xiang-Ming Wang, Antonio Pizzi, Luc Delmotte, Jean-Michel Hardy and Mailane Junkes RaizerDa Cruz, Int J Adhesion Adhesives, 2015, 63, 74-78; DOI:10.1016/j.ijadhadh.2015.08.007

12. Ying Wang, X Mo, X Susan Sun and Donghai Wang, J Appl Polym Sci., 2007, 104(1), 130-136; DOI:10.1002/app.24675 